\title{
Uji Transport Emulgel Minyak Atsiri Bunga Cengkeh dengan Penambahan Enhancer Propilen Glikol dan Asam Oleat
}

\author{
Muhammad Fariez Kurniawan', Nining Sugihartini², dan Tedjo Yuwono² \\ ${ }^{1}$ Program Studi Farmasi, Fakultas Kedokteran dan Ilmu Kesehatan Universitas Muhammadiyah Yogyakarta \\ ${ }^{2}$ Fakultas Farmasi Universitas Ahmad Dahlan, Yogyakarta
}

Korespondensi: Muhammad Fariez Kurniawan

Email: muhammadfariez@yahoo.co.id

Submitted : 26-11-2018, Revised : 27-01-2019, Accepted : 29-03-2019

\begin{abstract}
ABSTRAK: Kuncup bunga cengkeh mengandung senyawa eugenol yang merupakan minyak atsiri yang terbukti sebagai antiinflamasi. Untuk mendapatkan efek antiinflamasi yang optimal diperlukan suatu rancangan formulasi sediaan topikal berupa emulgel minyak atsiri bunga cengkeh (MABC) dengan penambahan enhancer kombinasi propilen glikol (PG) dan asam oleat (AO) yang dapat meningkatkan kemampuan eugenol dalam menembus lapisan kulit sehingga didapatkan daya antiinflamasi yang optimal dengan metode Simplex Lattice Design (SLD). Diformulasikan 3 formula emulgel dengan perbandingan PG dan AO dalam emulgel: 100\%:0\% (FI); 50\%:50\% (FII); dan 0\%:100\% (FIII). Masing-masing formula dilakukan uji transport dengan alat uji difusi tegak Franz menggunakan media kulit punggung mencit dan ditetapkan kadarnya menggunakan Kromatografi Cair Kinerja Tinggi (KCKT) serta diukur parameter uji transport yang meliputi daya permeabilitas, flux, koefisien difusi dan lag time. Data yang diperoleh dianalisis menggunakan metode SLD. Analisis data yang diperoleh menunjukkan adanya peningkatan pada parameter flux, permeabilitas, dan koefisien difusi serta penurunan pada lag time secara signifikan pada emugel dengan enhancer dibandingkan emulgel tanpa penambahan enhancer propilen glikol dan asam oleat. Diperoleh formulasi optimum emulgel MABC dengan penambahan 100\% enhancer propilen glikol sebagai formula yang mempunyai parameter flux, permeabilitas, koefisien difusi, dan lag time paling baik dan nilai enhancement ratio 1,05-1,94.
\end{abstract}

Kata kunci: emulgel; enhancer; propilen glikol; asam oleat; Simplex Lattice Design

\begin{abstract}
Clove contains eugenol, an essential oil compound, which has been proven to be anti-inflammatory agent. To obtain the optimal anti-inflammatory effect, a topical formulation design is needed in the form of clove oil emulgel with the addition of a combination of propylene glycol (PG) and oleic acid (OA) enhancers. These compounds are able to increase the ability of eugenol to penetrate the skin layer. Clove oil was formulated into 3 emulgel formulas with the addition of PG and OA in the ratio of: 100\%:0\% (FI); 50\%:50\% (FII); and 0\%:100\% (FIII), respectively. Each formula was tested by a transport test using Franz diffusion test using media skin of mice-back and the concentration was determined using High Performance Liquid Chromatography (HPLC) and measured transport test parameters including permeability, flux, diffusion coefficient, and lag time. The data obtained were analyzed using the Simplex Lattice Design (SLD) method. The result showed a significant increase in flux parameters, permeability, and diffusion coefficients and also a significant decrease in the lag time at the emulgel with enhancer, compared to the emulgel without the addition of enhancers. The optimum emulgel formulation was obtained by adding 100\% propylene glycol enhancer as a formula that has the best flux parameters, permeability, diffusion coefficient, and lag time and enhancement ratio value of 1.05 - 1.94.
\end{abstract}

Keywords: emulgel; enhancer, propylen glycol, oleic acid, Simplex Lattice Design 


\section{Pendahuluan}

Eugenol, merupakan minyak atsiri utama penyusun kuncup bunga cengkeh dan daun cengkeh. Kandungan eugenol pada kuncup bunga cengkeh sebesar 49,71\%, sedangkan pada daun cengkeh mencapai 74,28\% (1). Eugenol dikenal mempunyai efek antiinflamasi yang kuat. Pemberian eugenol $400 \mathrm{mg} / \mathrm{kg}$ secara oral mempunyai efek setara dengan indometasin dan celecoxib dalam menghambat munculnya edema pada kaki setelah 2-4 jam injeksi carrageenan (2), mengurangi inflamasi pada arthritis dan gejala flu (3). Pemberian minyak atsiri cengkeh $1 \%$ dalam sediaan salep yang mengandung 5\% menthol dan $15 \%$ metil salisilat mampu meningkatkan efek antiinflamasi nya sebesar 35\% (4), dan juga mencegah hiperpigmentasi pada kulit sehingga dapat berfungsi sebagai pemutih kulit (5). Minyak atsiri bunga cengkeh dalam formulasi emulgel juga mampu meningkatkan penetrasi asam mefenamat (6).

Carbomer (Carbomer 940) adalah polimer asam akrilat yang terhubung silang dengan polialkenil, polieter atau divinil glikol, merupakan polimer hidrofilik yang paling sering digunakan dalam formulasi gel. Hidrogel memiliki beberapa keunggulan, yaitu: mempunyai viskositas tinggi pada konsentrasi rendah, kesesuaian dengan banyak zat aktif, mempunyai sifat bioadesiv, termostabil, dan diterima pasien. Akan tetapi, hidrogel dapat meninggalkan lapisan tipis di kulit setelah pemakaian dikarenakan pelarutnya menguap. Oleh karena itu, dikombinasikan antara hidrogel dengan basis krim membentuk emulgel dan didapatkan manfaat yang lebih baik. Penambahan basis polimer dalam krim menghasilkan formasi hidrogel-basis krim dengan struktur gel di fase air. Hidrogel-basis krim dengan komponen minyak atsiri bunga cengkeh menghasilkan lapisan polimer berminyak pada kulit dan meningkatkan hidrasi kulit dengan mencegah hilangnya air transepidermal, dengan demikian berpotensi meningkatkan penetrasi molekul obat menembus kulit (7). Propilen glikol dan asam oleat sudah terbukti memiliki fungsi sebagai enhancer $(8,9)$. Propilen glikol meningkatkan penetrasi 5-aminolevulinic dalam menembus kulit hewan uji secara signifikan pada photodynamic therapy (10), memberikan rasio peningkatan gel Na diklofenak dengan basis carbopol sebesar 8 (11). Kombinasi propilen glikol dan asam oleat dalam formulasi carbopol meningkatkan absorbsi penetrasi dan absorbsi tenoxicam, serta meningkatan nilai flux dan menurunkan nilai lag time obat tersebut berdasarkan alat uji sel difusi Franz (12). Pada penelitian sebelumnya, telah dilakukan penelitian yang menghasilkan data bahwa emulgel minyak atsiri bunga cengkeh tanpa penambahan enhancer propilen glikol dan asam oleat mempunyai karakteristik sifat fisik yang baik dan tidak menimbulkan iritasi pada kulit hewan uji (13), hasil yang sama juga terdapat dalam sediaan krim tipe M/A (14). Hasil penelitian antiinflamasi minyak atsiri bunga cengkeh pada sediaan lotion (15) dan salep larut air (16) menunjukkan hasil bahwa pemberian propilen glikol sebagai enhancer mampu menurunkan ekspresi sel COX-2 dan sel inflamasi serta ketebalan epidermis. Tujuan dari penelitian ini adalah untuk mengetahui pengaruh pemberian enhancer asam oleat dan propilen glikol dalam emulgel untuk menaikkan kemampuan penetrasi emulgel minyak atsiri bunga cengkeh menembus lapisan kulit hewan uji menggunakan metode Simplex Lactice Design, sehingga didapatkan formula emulgel dengan nilai flux, lag time, permeabilitas, dan koefisien difusi yang terbaik.

\section{Alat, bahan, dan metode}

\subsection{Alat}

Peralatan yang digunakan dalam penelitian ini adalah timbangan analitik (Mettler Toledo), alat uji difusi tegak Franz, digital stirring hotplates (Thermo Fisher Scientific Cimarec), pH meter (SevenEasy Mettler Toledo), ultra thurax (IKA T18 Digital Homogenizer), waterbath (Memmert), instrumen KCKT (Shimadzu 00854 L207049), gunting bedah, scalpel, dan alat-alat 
gelas laboratorium (Iwaki Pyrex).

\subsection{Pengumpulan data}

Bahan yang digunakan dalam formulasi sediaan emulgel berderajad pharmaceutic grade meliputi carbopol 940, trietanolamin, propilen glikol, asam oleat, parafin cair, sorbitol, span 80 , tween 80 , metil paraben, propil paraben, aquadest dan crotton oil. Semua bahan untuk formulasi emulgel diperoleh dari PT. Brataco Chemica (Yogyakarta). Fase gerak yang digunakan untuk KCKT adalah asetonitril (p.a) dan asam asetat (p.a). Minyak atsiri yang digunakan dalam penelitian ini adalah minyak atsiri bunga cengkeh (MABC) yang diperoleh dari Center of Essential Oil Studies (CEOS) Universitas Islam Indonesia, Yogyakarta. Membran yang digunakan berasal dari kulit punggung mencit galur BALB/c.

\subsection{Metode}

\subsubsection{Formulasi emulgel}

Formula emulgel minyak atsiri bunga cengkeh yang digunakan pada penelitian ini disajikan pada tabel 1.

\subsubsection{Evaluasi uji transport secara in vitro}

Uji ini dilakukan dengan menggunakan alat uji difusi tegak Franz. Digunakan kulit punggung mencit sebagai membran yang diletakkan di antara kompartemen donor dan aseptor. Kompartemen donor berisi satu gram emulgel sedangkan aseptor berupa larutan dapar fosfat $\mathrm{pH}$ 7,4 sebanyak $50 \mathrm{~mL}$. Pada saat uji transport suhu pada kompartemen aseptor dijaga tetap $37^{\circ} \mathrm{C}$ dengan pengadukan menggunakan stirrer pada skala 6 . Volume larutan sampel sejumlah 1,0 mL diambil dari kompartemen aseptor dalam rentang waktu 26 jam $(0,5 ; 1 ; 2 ; 3 ; 4 ; 5 ; 6 ; 24$; dan 26 jam). Pada saat setelah pengambilan volume sampel maka langsung ditambahkan 1,0 mL larutan dapar fosfat $\mathrm{pH}$ 7,4. Kadar eugenol dalam setiap sampel ditetapkan nilai AUC nya dengan KCKT untuk kemudian dihitung kadarnya. Fase gerak yang digunakan adalah asetonitril : asam asetat $1 \%$ (80:20), dengan kolom C18 sebagai fase diam. Eluasi dilakukan dengan kecepatan alir $1 \mathrm{ml} / \mathrm{me}$ nit dan panjang gelombang pengamatan $280 \mathrm{~nm}$.

Berdasarkan nilai AUC yang diperoleh kemudian dihitung flux, lag time, dan permeabilitas serta koefisien difusi. Nilai flux menunjukkan jumlah dan kecepatan zat melalui suatu bidang dengan luas $1 \mathrm{~cm}^{2}$ per satuan waktu. Nilai flux dikalkulasikan dari nilai slope hasil regresi linier hubungan antara waktu (t) vs jumlah obat per

Tabel 1. Formula minyak atsiri bunga cengkeh dalam sediaan emulgel

\begin{tabular}{lllll}
\hline Bahan & \multicolumn{2}{l}{ Formula (g) } & & \\
\cline { 2 - 5 } & I & II & III & IV \\
\hline Minyak atsiri bunga cengkeh & 10 & 10 & 10 & 10 \\
Carbopol 940 & 4 & 4 & 4 & 4 \\
Propilen glikol & 10 & 5 & - & - \\
Asam oleat & - & 5 & 10 & - \\
TEA & 8 & 8 & 8 & 8 \\
Sorbitol & 2 & 2 & 2 & 2 \\
\hline Parafin cair & 1,25 & 1,25 & 1,25 & 1,25 \\
Span 80 & 2,5 & 2,5 & 2,5 & 2,5 \\
Tween 80 & 17,5 & 17,5 & 17,5 & 17,5 \\
Metil paraben & 0,18 & 0,18 & 0,18 & 0,18 \\
Propil paraben & 0,02 & 0,02 & 0,02 & 0,02 \\
Air suling ad & 100 & 100 & 100 & 100 \\
\hline
\end{tabular}


satuan luas permukaan membran (MFk/A) (17). Nilai lag time merupakan nilai "X" hasil dari persamaan regresi linier hubungan antara waktu $(\mathrm{t})$ vs jumlah obat per satuan luas permukaan membran (MFk/A) pada saat "Y" (respon) = 0. Nilai permeabilitas didapatkan dari slope hasil regresi linier hubungan antara $\mathrm{t}$ vs Mk F/A tiap formula dibagi dengan konsentrasi emulgel di dalam kompartemen donor. Nilai koefisien difusi diperoleh dari hasil pembagian antara nilai kuadrat tebal membran (h2) dengan 6tL (Lag time).

\subsubsection{Perhitungan komposisi formula optimum}

Nilai flux, lag time, permeabilitas dan koefisien difusi yang didapatkan dihitung menggunakan persamaan Simplex Lattice Design sehingga diperoleh formula emulgel dengan komposisi enhancer kombinasi propilen glikol dan asam oleat yang terbaik.

$$
\begin{aligned}
& Y=a(A)+b(B)+a b(A)(B) \ldots \ldots . . .(1) \\
& \text { di mana: } \\
& \mathrm{Y} \quad: \text { hasil uji } \\
& \mathrm{A} \quad: \text { komposisi propilen glikol } \\
& \mathrm{B} \quad: \text { komposisi asam oleat } \\
& \mathrm{a} \quad: \text { koefisien propilen glikol } \\
& \mathrm{b} \quad \text { : koefisien asam oleat } \\
& \text { a,b : koefisien propilen glikol dan asam } \\
& \quad \text { oleat }
\end{aligned}
$$

Penentuan formula optimal didapatkan dari respon total yang paling besar berdasarkan perhitungan normalisasi dari parameter flux, lag time, permeabilitas, dan koefisien difusi yang memiliki perbedaan signifikan antar formula. Penentuan komposisi kombinasi propilen glikol dan asam oleat sebagai enhancer diperoleh dari penjumlahan nilai respon flux (R1); lag time (R2); permeabilitas (R3); dan koefisien difusi (R4) dengan pembobotan sebagaimana persamaan berikut:

$\mathrm{R} 1=\mathrm{N} 1 \times 0,3 ; \mathrm{R} 2=\mathrm{N} 2 \times 0,2 ; \mathrm{R} 3=\mathrm{N} 3 \times 0,3 ;$ dan $\mathrm{R} 4=\mathrm{N} 4 \times 0,4$

Di mana:

$$
\begin{aligned}
& N=\frac{X-X \min }{X \max -X \min } \\
& \mathrm{X} \quad \text { : respon masing-masing uji } \\
& \mathrm{Xmin}: \text { respon minimal yang diinginkan } \\
& \text { Xmax : respon maksimal yang diinginkan (18) }
\end{aligned}
$$

Selanjutnya diperhitungkan nilai $\mathrm{R}$ total yang merupakan hasil penjumlahan dari nilai R1, R2, R3, dan R4. Nilai R total yang tertinggi merupakan formulasi emulgel minyak atsiri bunga cengkeh dengan nilai flux, lag time, permeabilitas, dan koefisien difusi yang terbaik.

\section{Hasil dan pembahasan}

Uji transport dilakukan untuk mengetahui kemampuan eugenol sebagai zat aktif dan pengaruh pemberian enhancer propilen glikol dan asam oleat dalam menembus lapisan kulit mencit. Nilai hasil uji transport ditunjukkan pada tabel 2, sedangkan nilai enhancement ratio (ER) diperlihatkan pada tabel 3.

Semakin besar nilai flux maka kecepatan penetrasi obat dalam menembus lapisan kulit akan semakin besar (19). Pada formula I dan II memiliki nilai flux yang lebih rendah jika dibandingkan dengan formula III, namun masih lebih tinggi daripada formula emulgel MABC yang tanpa diberikan enhancer propilen glikol dan asam oleat. Hal ini membuktikan bahwa propilen glikol dan asam oleat sebagai enhancer mampu meningkatkan kemampuan penetrasi eugenol dalam menembus lapisan stratum korneum. Propilen glikol dapat meningkatkan harga flux dengan cara berinteraksi dengan bilayer fosfolipid yang dapat membuat lapisan kulit menjadi fleksibel sehingga penetrasi obat dalam menembus lapisan kulit akan semakin meningkat (20). Dari hasil yang diperoleh dapat diketahui bahwa asam oleat mempunyai efek yang lebih besar dalam meningkatkan flux emulgel MABC dibandingkan propilen glikol dan kombinasi propilen glikol dengan asam oleat.

Berdasarkan perhitungan Simplex Lattice De- 
Tabel 2. Hasil uji transport eugenol antar formula

\begin{tabular}{lllll}
\hline Parameter Uji Transport & Formula & & \\
\cline { 2 - 5 } & I & II & III & IV \\
\hline Flux $\left(\mathrm{mg} / \mathrm{cm}^{2} / \mathrm{jam}\right)$ & $0,0752 \pm 0,0014$ & $0,0610 \pm 0,0018$ & $0,1090 \pm 0,0025$ & $0,0568 \pm 0,0024$ \\
Lag time $(\mathrm{jam})$ & $1,46 \pm 0,06$ & $2,43 \pm 0,06$ & $2,68 \pm 0,01$ & $2,83 \pm 0,01$ \\
Permeabilitas $(\mathrm{cm} /$ detik) & $2,08 \times 10^{-7} \pm$ & $1,69 \times 10^{-7} \pm$ & $3,02 \times 10^{-7} \pm$ & $1,57 \times 10^{-7} \pm$ \\
& $4,08 \times 10^{-9}$ & $5,13 \times 10^{-9}$ & $7,17 \times 10^{-9}$ & $6,83 \times 10^{-9}$ \\
Koefisien difusi $\left(\mathrm{cm}^{2} /\right.$ detik) & $2,20 \times 10^{-6} \pm$ & $1,32 \times 10^{-6} \pm$ & $1,20 \times 10^{-6} \pm$ & $1,13 \times 10^{-6} \pm$ \\
& $9,49 \times 10^{-8}$ & $3,50 \times 10^{-8}$ & $6,75 \times 10^{-9}$ & $3,60 \times 10^{-9}$ \\
\hline
\end{tabular}

Tabel 3. Nilai ER uji transport eugenol antar enhancer

\begin{tabular}{lllll}
\hline Enhancer & ER Flux & ER Lag Time & ER Permeabilitas & ER Koefisien Difusi \\
\hline 100\% propilen glikol & 1,32 & 1,93 & 1,32 & 1,94 \\
$\begin{array}{l}\text { 50\% propilen glikol, 50\% } \\
\text { asam oleat }\end{array}$ & 1,07 & 1,16 & 1,07 & 1,16 \\
100\% asam oleat & 1,91 & 1,05 & 1,92 & 1,06 \\
\hline
\end{tabular}

ER: perbandingan antara nilai parameter uji transport enhancer dengan tanpa enhancer

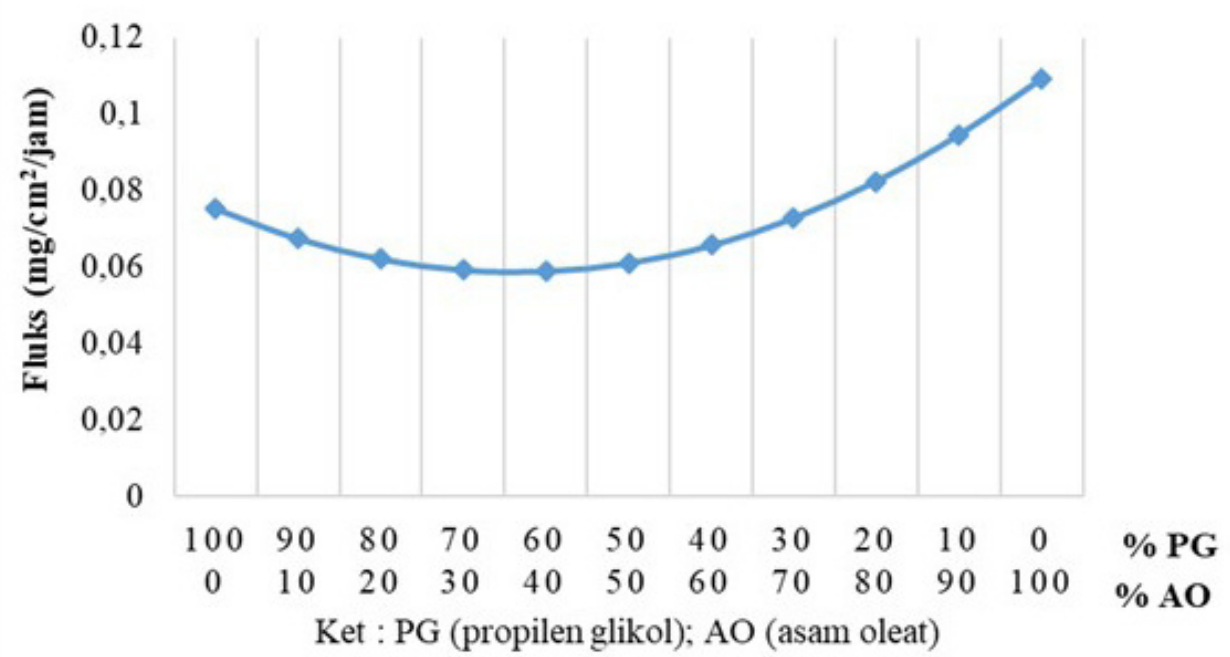

Gambar 1. Grafik hubungan antara komposisi enhancer propilen glikol dan asam oleat terhadap nilai flux

sign komposisi optimum berdasarkan nilai flux adalah formula III yang mempunyai komposisi enhancer $100 \%$ asam oleat. Grafik hubungan antara komposisi enhancer propilen glikol dan asam oleat dalam emulgel MABC terhadap nilai flux disajikan pada gambar 1 .

Parameter lag time menunjukkan waktu yang dibutuhkan obat untuk menembus membran sehingga dapat mencapai kompartemen reseptor. Semakin besar nilai lag time maka penetrasi obat dalam menembus lapisan kulit akan semakin kecil, dan sebaliknya semakin kecil nilai lag time maka penetrasi obat dalam menembus lapisan kulit akan semakin besar (17). Berdasarkan hasil penelitian, perbandingan nilai lag time FI $(1,46$ jam $)<$ FII $(2,43$ jam $)<$ FIII $(2,68$ jam $)<$ $\mathrm{F}$ tanpa enhancer (2,83 jam). Berdasarkan perhitungan Simplex Lattice Design komposisi formula dengan nilai lag time paling kecil adalah FI yang mengandung komposisi enhancer $100 \%$ propilen 
glikol. Hal ini menunjukkan bahwa semakin besar penambahan enhancer propilen glikol akan menurunkan nilai lag time sehingga penetrasi obat akan semakin besar. Hal ini disebabkan karena propilen glikol dapat berinteraksi dengan lapisan fosfolipid pada kulit yang dapat membuat lapisan kulit menjadi fleksibel sehingga waktu yang diperlukan obat untuk menembus lapisan kulit akan semakin cepat (20). Emulgel F tanpa enhancer mempunyai nilai lag time yang paling besar dibandingkan dengan FI, FII, dan FIII. Hal ini menunjukkan bahwa enhancer propilen glikol dan asam oleat mampu menurunkan daya lag time emulgel minyak atsiri bunga cengkeh secara signifikan. Grafik hubungan antara komposisi enhancer propilen glikol dan asam oleat dalam emulgel minyak atsiri bunga cengkeh terhadap nilai lag time disajikan pada gambar 2 .

Parameter permeabilitas digunakan untuk menunjukkan kemampuan dari suatu membran untuk dapat dilewati suatu obat. Semakin besar nilai permeabilitas akan meningkatkan penetrasi obat dalam menembus lapisan kulit (19). Nilai permeabilitas diperoleh dari hasil pembagian antara nilai flux dengan konsentrasi emulgel MABC dalam uji transport (17).

Berdasarkan hasil penelitian, perbandingan nilai permeabilitas FIII $\left(3,02 \times 10^{-7} \mathrm{~cm} \mathrm{detik}^{-1}\right)$ $>$ FI $\left(2,08 \times 10^{-7} \mathrm{~cm} \mathrm{detik}^{-1}\right)>$ FII $\left(1,69 \times 10^{-7} \mathrm{~cm}\right.$ $\left.\operatorname{detik}^{-1}\right)>\mathrm{F}$ tanpa enhancer $\left(1,57 \times 10^{-7} \mathrm{~cm}^{-1 e t i k^{-1}}\right)$. Berdasarkan perhitungan Simplex Lattice Design komposisi optimum terhadap nilai permeabilitas pada perbandingan formula $40 \%$ propilen glikol : $60 \%$ asam oleat. Nilai permeabilitas sebanding dengan nilai flux. Semakin besar nilai flux maka nilai permeabilitas juga akan semakin besar, karena berdasarkan persamaan nilai koefisien permeabilitas adalah harga flux/Cp (17). Hasil penelitian menunjukkan bahwa propilen glikol dan asam oleat sebagai enhancer mampu meningkatkan kemampuan permeabilitas pada sediaan emulgel secara signifikan dibandingkan dengan kelompok F tanpa enhancer. Grafik hubungan antara komposisi enhancer propilen glikol dan asam oleat dalam emulgel MABC terhadap nilai permeabilitas disajikan pada gambar 3 .

Parameter koefisien difusi (D) digunakan untuk menggambarkan jumlah obat yang terdifusi dalam satuan luas membran per satuan waktu. Semakin besar nilai koefisien difusi maka jumlah obat yang masuk dan berpenetrasi menembus kulit akan semakin meningkat. Nilai koefisien difusi diperoleh dari hasil pembagian antara nilai kuadrat tebal membran (h2) dengan 6tL ( Lag time) dalam uji transport (17).

Berdasarkan hasil penelitian, perbandingan nilai koefisien difusi FI $\left(2,20 \times 10^{-6} \mathrm{~cm}^{2} \operatorname{detik}^{-1}\right)>$ FII $\left(1,32 \times 10^{-6} \mathrm{~cm}^{2} \operatorname{detik}^{-1}\right)>$ FIII $\left(1,20 \times 10^{-6} \mathrm{~cm}^{2} \mathrm{de}-\right.$ tik $\left.^{-1}\right)>\mathrm{F}$ tanpa enhancer $\left(1,13 \times 10^{-6} \mathrm{~cm}^{2}\right.$ detik $\left.^{-1}\right)$. Berdasarkan perhitungan Simplex Lattice Design komposisi optimum terhadap nilai koefisien difusi pada FI. Nilai koefisien difusi memiliki korelasi dengan nilai lag time. Semakin besar nilai koefisien difusi maka nilai lag time akan semakin kecil, karena berdasarkan persamaan bahwa koefisien difusi (D) adalah h2/6tL (17). Grafik hubungan antara komposisi enhancer propilen glikol dan asam oleat dalam emulgel MABC terhadap nilai koefisien difusi disajikan pada gambar 4 .

Penentuan formula terbaik dtentukan dengan persamaan metode Simplex Lattice Design. Hasil nilai respon total enhancer propilen glikol dan asam oleat ditunjukkan pada tabel 4. Nilai respon total menunjukkan bahwa emulgel dengan enhancer $100 \%$ propilen glikol mempunyai profil flux, lag time, permeabilitas dan koefisien difusi terbaik.

\section{Kesimpulan}

Enhancer propilen glikol dan asam oleat mampu meningkatkan nilai flux, permeabilitas dan koefisien difusi serta menurunkan nilai lag time dengan nilai enhancement ratio 1,05 - 1,94. Formula terbaik dengan respon flux, lag time, permeabilitas serta koefisien difusi terbaik adalah emulgel dengan penambahan enhancer 100\% propilen glikol. 


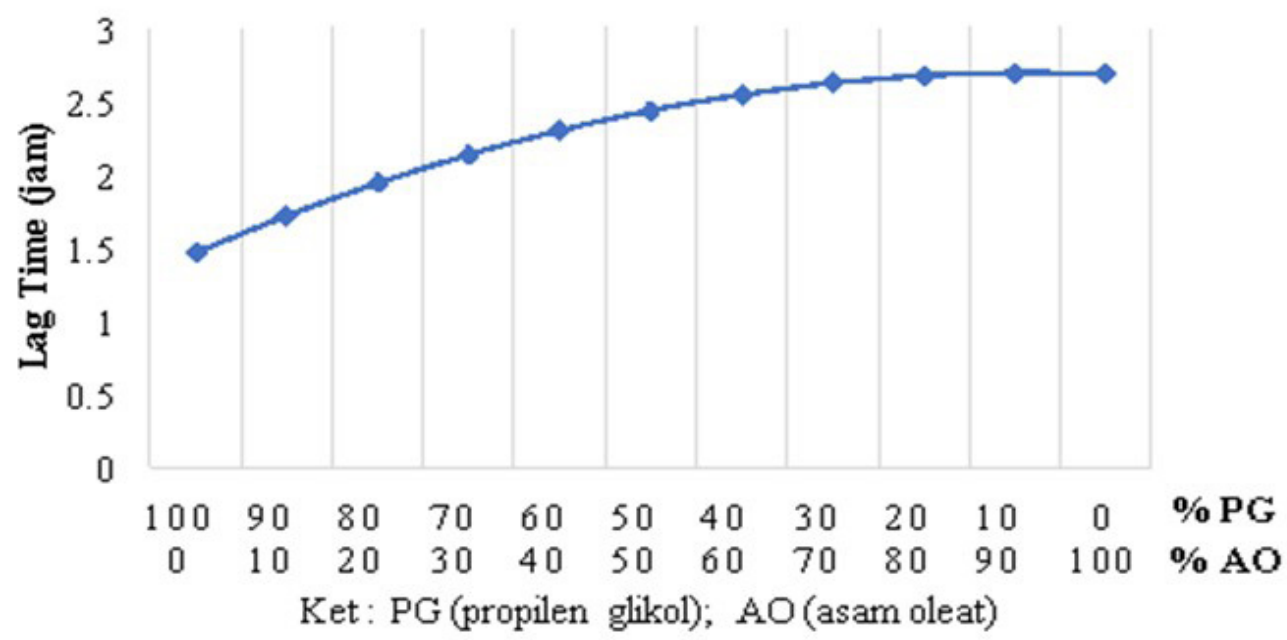

Gambar 2. Grafik hubungan antara komposisi enhancer propilen glikol dan asam oleat terhadap nilai lag time

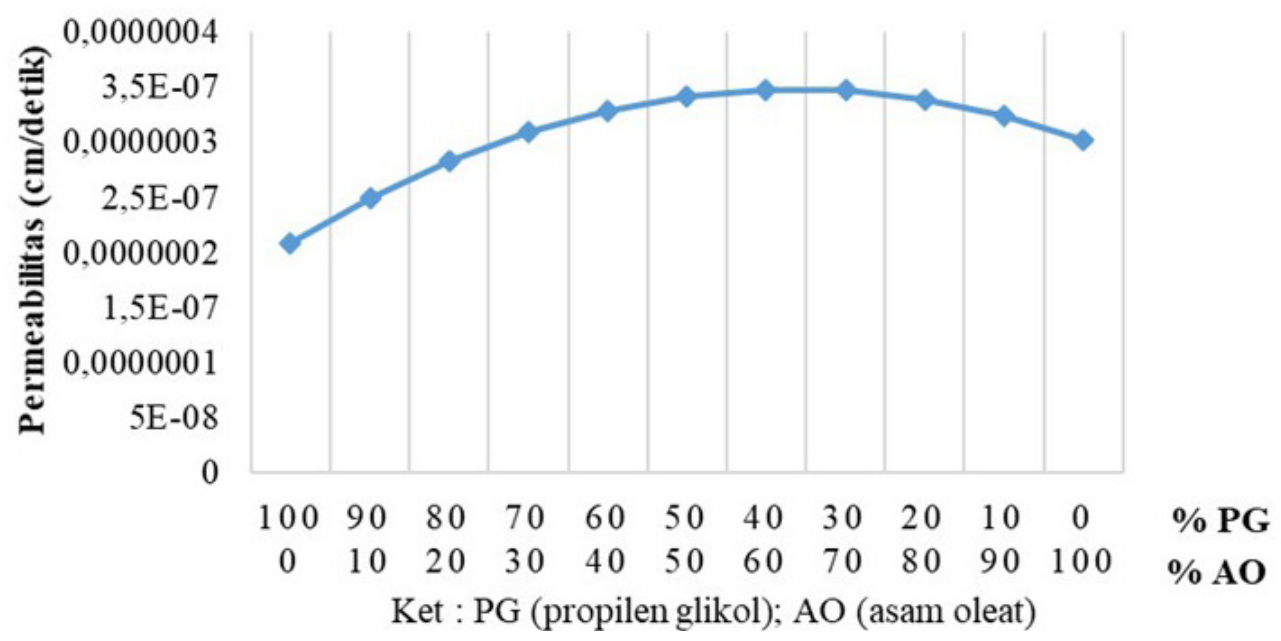

Gambar 3. Grafik hubungan antara komposisi enhancer propilen glikol dan asam oleat terhadap nilai permeabilitas

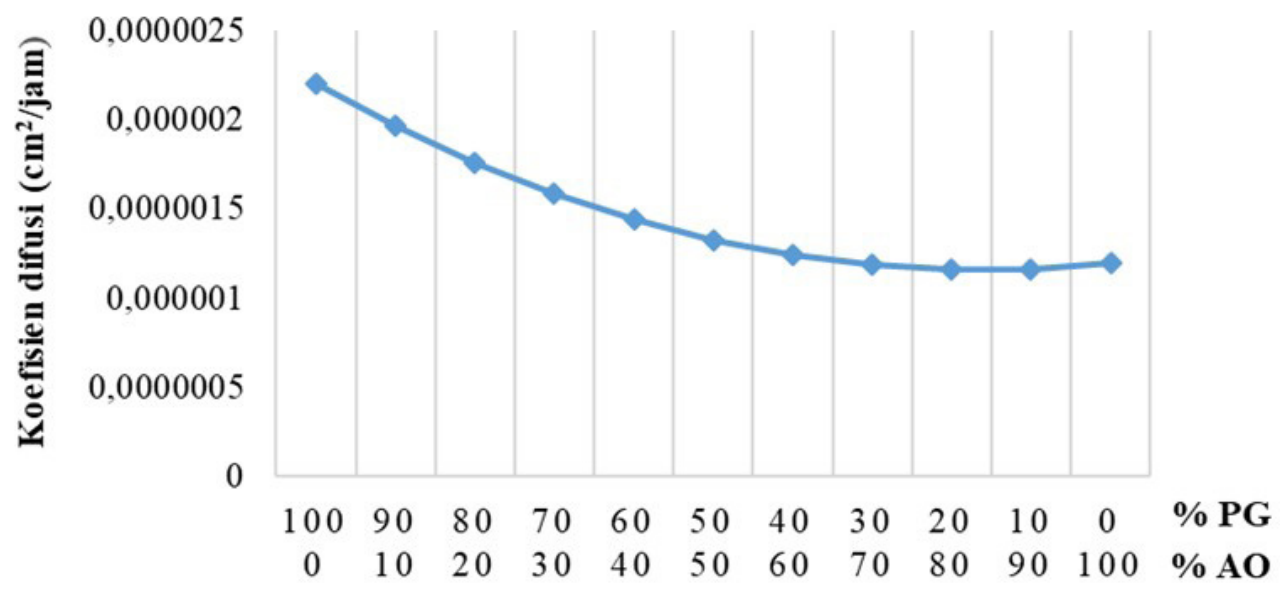

Ket : PG (propilen glikol); AO (asam oleat)

Gambar 4. Grafik hubungan antara komposisi enhancer propilen glikol dan asam oleat terhadap nilai koefisien difusi 
Tabel 4. Hasil respon total enhancer kombinasi propilen glikol : asam oleat

\begin{tabular}{llllll}
\hline $\begin{array}{l}\text { Propilen glikol : } \\
\text { asam oleat }\end{array}$ & R fluks & $\begin{array}{l}\text { ER Lag } \\
\text { Time }\end{array}$ & ER Permeabilitas & $\begin{array}{l}\text { ER Koefisien } \\
\text { Difusi }\end{array}$ & $\begin{array}{l}\text { ER Koefisien } \\
\text { Difusi }\end{array}$ \\
\hline $100 \%: 0 \%$ & 0,09761 & 0,2 & 0 & 0,2 & 0,49761 \\
\hline $90 \%: 10 \%$ & 0,05089 & 0,15901 & 0,0872 & 0,144263 & 0,441363 \\
\hline $80 \%: 20 \%$ & 0,01904 & 0,12271 & 0,15952 & 0,097581 & 0,398851 \\
\hline $70 \%: 30 \%$ & 0,00208 & 0,0911 & 0,21696 & 0,059955 & 0,370095 \\
\hline $60 \%: 40 \%$ & 0 & 0,06419 & 0,25952 & 0,031383 & 0,355093 \\
\hline $50 \%: 50 \%$ & 0,0128 & 0,04197 & 0,2872 & 0,011867 & 0,353837 \\
\hline $40 \%: 60 \%$ & 0,04048 & 0,02444 & 0,3 & 0,001406 & 0,366326 \\
\hline $30 \%: 70:$ & 0,08304 & 0,0116 & 0,29792 & 0 & 0,39256 \\
\hline $20 \%: 80 \%$ & 0,14048 & 0,00345 & 0,28096 & 0,007649 & 0,432539 \\
\hline $10 \%: 90 \%$ & 0,2128 & 0 & 0,24912 & 0,024354 & 0,486274 \\
\hline $0 \%: 100 \%$ & 0,3 & 0,00124 & 0,20239 & 0,050113 & 0,553743 \\
\hline
\end{tabular}

\section{Ucapan Terimakasih}

Penelitian ini mendapatkan dana bantuan Hibah DIKTI melalui skema penelitian Tim Pasca Sarjana Tahun Anggaran 2016.

\section{Daftar Pustaka}

1. Kamatou GP, Vermaak I, Viljoen AM. Eugenolfrom the remote Maluku Islands to the international market place: a review of a remarkable and versatile molecule. Molecules. 2012;17(6):6953-81.

2. Daniel AN, Sartoretto SM, Schmidt G, CaparrozAssef SM, Bersani-Amado CA, Cuman RK. Antiinflammatory and antinociceptive activities A of eugenol essential oil in experimental animal models. Revista Brasileira de Farmacognosia. 2009;19(1B):212-7.

3. Bhuiyan MN, Begum J, Akter F. Constituents of the essential oil from leaves and buds of clove (Syzigium caryophyllatum (L.) Alston). African Journal of Plant Science. 2010;4(11):451-4.

4. Mehta NJ, Patadiya ND, Patel J, Shastri DH, Shelat PK. Development and evaluation of antiarthritic herbal ointment. Research Journal of Pharmaceutical biological and chemical. 2013;4:221-8.
5. Arung ET, Matsubara E, Kusuma IW, Sukaton E, Shimizu K, Kondo R. Inhibitory components from the buds of clove (Syzygium aromaticum) on melanin formation in B16 melanoma cells. Fitoterapia. 2011;82(2):198-202.

6. Khullar R, Kumar D, Seth N, Saini S. Formulation and evaluation of mefenamic acid emulgel for topical delivery. Saudi pharmaceutical journal. 2012;20(1):63-7.

7. Lee SG, Kim SR, Cho HI, Kang MH, Yeom DW, Lee SH, Lee S, Choi YW. Hydrogel-based ultramoisturizing cream formulation for skin hydration and enhanced dermal drug delivery. Biological and Pharmaceutical Bulletin. 2014;37(10):1674-82.

8. Bendas B, Schmalfu $\beta$ U, Neubert R. Influence of propylene glycol as cosolvent on mechanisms of drug transport from hydrogels. International journal of pharmaceutics. 1995;116(1):19-30.

9. Engelbrecht TN, Schroeter A, Hauß T, Neubert RH. Lipophilic penetration enhancers and their impact to the bilayer structure of stratum corneum lipid model membranes: neutron diffraction studies based on the example oleic acid. Biochimica et Biophysica Acta (BBA)Biomembranes. 2011;1808(12):2798-806.

10. Steluti R, De Rosa FS, Collett J, Tedesco AC, Bentley MV.Topical glycerol monooleate/propylene glycol 
formulations enhance 5-aminolevulinic acid in vitro skin delivery and in vivo protophorphyrin IX accumulation in hairless mouse skin. European journal of pharmaceutics and biopharmaceutics. 2005;60(3):439-44.

11. Arellano A, Santoyo S, Martın C, Ygartua P. Influence of propylene glycol and isopropyl myristate on the in vitro percutaneous penetration of diclofenac sodium from carbopol gels. European journal of pharmaceutical sciences. 1999;7(2):129-35.

12. Larrucea E, Arellano A, Santoyo S, Ygartua P. Combined effect of oleic acid and propylene glycol on the percutaneous penetration of tenoxicam and its retention in the skin. European journal of pharmaceutics and biopharmaceutics. 2001;52(2):113-9.

13. Sari DK, Sugihartini N, Yuwono T. Evaluasi Uji Iritasi dan Uji Sifat Fisik Sediaan Emulgel Minyak Atsiri Bunga Cengkeh (Syzigium aromaticum). Pharmaciana. 2015;5(2):115-20.

14. Haque AF, Sugihartini N. Evaluasi Uji Iritasi Dan Uji Sifat Fisik Pada Sediaan Krim M/A Minyak Atsiri Bunga Cengkeh Dengan Berbagai Variasi Konsentrasi. Jurnal Farmasi Indonesia" PHARMACY". 2015;12(2):131-9.

15. Iriani FA, Sugihartini N, Yuwono T. The Profile of Anti-inflammatory Activity of Syzigium Aromaticum Volatile Oil in Lotion with Variation
Composition of Oleic Acid and Propylene Glycol as Enhancer. Majalah Obat Tradisional (Traditional Medicine Journal). 2017;22(2):111-5.

16. Rahmawati D, Sugihartini N, Yuwono T. Antiinflammatory Activity of Ointment in Water Soluble Base of Volatile Oil of Syzygium aromaticum with Variation Composition of Oleic acid and Propylene glycol as Enhancer. Berkala Ilmu Kesehatan Kulit dan Kelamin. 2017;29(3):182-7.

17. Rakesh R, Anoop KR. Formulation and optimization of nano-sized ethosomes for enhanced transdermal delivery of cromolyn sodium. Journal of pharmacy \& bioallied sciences. 2012;4(4):333-40.

18. Bolton S, Bon C. Pharmaceutical Statistics: Practical and Clinical Applications. Fourth Edition, Revised and Expanded. New York, Basel: Marcel Dekker, Inc; 2004:523-31.

19. Banweer J, Pathaka AK, Pandey S. Development and optimization of transdermal system of lisinopril dehydrate: Employing permeation enhancers. Iranian Journal of Pharmaceutical Sciences. 2012;8(4):245-51.

20. Elmoslemany RM, Abdallah OY, El-Khordagui LK, Khalafallah NM. Propylene glycol liposomes as a topical delivery system for miconazole nitrate: comparison with conventional liposomes. AAPS PharmSciTech. 2012;13(2):723-31. 